\title{
Kidney re-transplantation in a child across the barrier of persisting angiotensin II type I receptor antibodies
}

\author{
Annika Gold $^{1}$ (D) Alexander Fichtner ${ }^{1} \cdot$ Daniela Choukair $^{1} \cdot$ Claus Peter Schmitt $^{1} \cdot$ Caner Süsal $^{2}$ (D) Duska Dragun $^{3,4}$. \\ Burkhard Tönshoff ${ }^{1}$ (B)
}

Received: 3 September 2020 / Revised: 25 October 2020 / Accepted: 26 November 2020 / Published online: 23 December 2020

(C) The Author(s) 2020

\begin{abstract}
Background Approximately 20\% of antibody-mediated rejection (ABMR) episodes in the absence of donor-specific antibodies against human leucocyte antigens (HLA-DSA) in pediatric and adult kidney transplant recipients are associated with, and presumably caused by, antibodies against the angiotensin type 1 receptor $\left(A_{1} R-A b\right)$. While the role of $A T_{1} R-A b$ for $A B M R$ and graft failure is increasingly recognized, there is little information available on the management of these patients for retransplantation over the barrier of persisting $\mathrm{AT}_{1} \mathrm{R}-\mathrm{Ab}$.

Case We report on a male patient with kidney failure in infancy due to obstructive uropathy who had lost his first kidney transplant due to $\mathrm{AT}_{1} \mathrm{R}-\mathrm{Ab}$-mediated chronic $\mathrm{ABMR}$. Because this antibody persisted during 4 years of hemodialysis, for the 2nd kidney transplantation (living-related transplantation from his mother), he underwent a desensitization regimen consisting of 15 plasmapheresis sessions, infusions of intravenous immunoglobulin $\mathrm{G}$ and thymoglobulin, as well as pharmacological blockade of the Angiotensin II (AT II) pathway by candesartan. This intense desensitization regimen transiently decreased elevated $\mathrm{AT}_{1} \mathrm{R}-\mathrm{Ab}$ titers, resulting in stable short-term kidney allograft function. The subsequent clinical course, however, was complicated by acute cellular rejection and chronic ABMR due to persistent $\mathrm{AT}_{1} \mathrm{R}-\mathrm{Ab}$ and de novo HLA-DSA, which shortened allograft survival to a period of only 4 years.

Conclusion This case highlights the difficulty of persistently decreasing elevated $\mathrm{AT}_{1} \mathrm{R}-\mathrm{Ab}$ titers by a desensitization regimen for re-transplantation and the detrimental effect of the interplay between $\mathrm{AT}_{1} \mathrm{R}-\mathrm{Ab}$ and HLA-DSA on kidney transplant survival.
\end{abstract}

Keywords Kidney transplantation · Antibody-mediated rejection $\cdot$ Angiotensin type 1 receptor antibodies $\cdot$ Donor-specific HLA antibodies

\section{Introduction}

Antibody-mediated rejection (ABMR) plays a significant role in graft loss in both adult [1-3] and pediatric kidney transplant recipients $[2,4]$. The majority of these rejections

Annika Gold

annika.gold@med.uni-heidelberg.de

1 Department of Pediatrics I, University Children's Hospital Heidelberg, Im Neuenheimer Feld 430, 69120 Heidelberg, Germany

2 Institute of Immunology, University Hospital Heidelberg, Heidelberg, Germany

3 Clinic for Nephrology and Critical Care Medicine, Charité-Universitätsmedizin Berlin, Berlin, Germany

4 Berlin Institute of Health, Berlin, Germany are caused by pre-formed and/or de novo donor-specific antibodies against human leucocyte antigens (HLA-DSA). However, there is a significant subset of patients with histological features of ABMR in the graft biopsy, in whom HLADSA cannot be detected in the circulation $[5,6]$. In recent years, therefore, there have been increasing efforts directed towards the detection and biological characterization of antibodies against other endothelial targets beside HLA. In the year 2005, the discovery of antibodies against the angiotensin type 1 receptor $\left(A_{1} R\right)$ in patients undergoing $A B M R$ without detectable HLA-DSA by Dragun et al. significantly increased our understanding of the role of non-HLA antibodies in the pathophysiology of ABMR [7]. Approximately $20 \%$ of ABMR episodes in the absence of HLA-DSA in pediatric and adult kidney transplant recipients are associated with, and presumably caused by, $\mathrm{AT}_{1} \mathrm{R}$ antibodies $\left(\mathrm{AT}_{1} \mathrm{R}-\mathrm{Ab}\right)[8,9]$. 
$\mathrm{AT}_{1} \mathrm{R}-\mathrm{Ab}$ are a group of receptor-activating antibodies (agonists) inducing downstream events such as vasoconstriction, remodeling of the extracellular matrix, and induction of proinflammatory cascades [10]. It has been hypothesized that ischaemia-reperfusion injury increases the expression of donor $\mathrm{AT}_{1} \mathrm{R}$ on vascular smooth-muscle and endothelial cells, predisposing the graft to injury by pre-existing $\mathrm{AT}_{1} \mathrm{R}-\mathrm{Ab}[11]$. Furthermore, $\mathrm{AT}_{1} \mathrm{R}-\mathrm{Ab}$ upregulate HLA class II antigens on endothelial cells, thereby potentially enhancing the detrimental effects of HLA-DSA [6]. A few case reports have highlighted the broad spectrum of different clinical phenotypes of $\mathrm{AT}_{1} \mathrm{R}-\mathrm{Ab}$-mediated tissue injury [12-15].

While the role of $\mathrm{AT}_{1} \mathrm{R}-\mathrm{Ab}$ for $\mathrm{ABMR}$ and graft failure is increasingly recognized, there is little information available on the management of these patients for re-transplantation over the barrier of persisting $\mathrm{AT}_{1} \mathrm{R}-\mathrm{Ab}$. We therefore report here the desensitization for re-transplantation and long-term follow-up of a pediatric patient, who had lost his first kidney allograft due to $\mathrm{AT}_{1} \mathrm{R}-\mathrm{Ab}$-mediated $\mathrm{ABMR}$.

\section{Case report}

We report on a male patient with chronic kidney disease stage 5 in infancy due to obstructive uropathy. He received a first kidney transplant at the age of 3.2 years from a deceased female donor (42 years of age, one HLA-A and one HLADR mismatch) in the year 2000 .

The initial immunosuppressive therapy consisted of cyclosporin A microemulsion (CsA), mycophenolate mofetil (MMF), and methylprednisolone. On day 7 post-transplant, during a period of inadequate CsA exposure, he experienced acute $\mathrm{T}$ cell-mediated rejection with mild to moderate intimal arteritis (BANFF '97 Grade IIa), which was treated with methylprednisolone pulses, OKT3, and switch of CsA to tacrolimus. Thereafter, graft function was stable for 6 years posttransplant with a serum creatinine concentration of approximately $1.4 \mathrm{mg} / \mathrm{dL}$. He then experienced a progressive decline of graft function (increase of serum creatinine to $2.5 \mathrm{mg} / \mathrm{dL}$ ) accompanied by severe arterial hypertension. Kidney allograft biopsy revealed chronic transplant glomerulopathy with partial glomerular sclerosis, interstitial fibrosis and tubular atrophy (IFTA), mild tubulitis, and arterial intimal fibrosis of new onset; $\mathrm{C} 4 \mathrm{~d}$ staining by immunohistochemistry was negative. These histopathological lesions were at the time categorized as acute vascular and interstitial rejection (BANFF IIb). With today's histopathological classification, these lesions were consistent with chronic active ABMR. There was no serological evidence of HLA-DSA measured by the LABScreen Single Antigen assays (OneLambda, Thermofischer Scientific Canoga Park, CA), but the serum concentration of $\mathrm{AT}_{1} \mathrm{R}-\mathrm{Ab}$ was markedly elevated $(112 \mathrm{U} / \mathrm{L}$, reference range $<10 \mathrm{U} / \mathrm{L}) . \mathrm{AT}_{1} \mathrm{R}-\mathrm{Ab}$ were initially measured with a bioassay
[7], subsequently with a cell-based enzyme-linked immunosorbent assay (ELISA) (CellTrend GmbH, Luckenwalde, Germany, now OneLambda, Thermofischer Scientific Canoga Park, CA). The categories of binding reported in the ELISA test usually indicate negative binding at $<10 \mathrm{U} / \mathrm{mL}$ and lower, intermediate binding at $10-17 \mathrm{U} / \mathrm{mL}$, and strong binding at $>17 \mathrm{U} / \mathrm{mL}[16]$. Endothelin type A receptor antibodies $\left(\mathrm{ET}_{\mathrm{A}} \mathrm{R}-\mathrm{Ab}\right)$ were also measured with a sandwich ELISA (CellTrend GmbH, Luckenwalde, Germany, now OneLambda, Thermofischer Scientific Canoga Park, CA). As the potential role of $\mathrm{AT}_{1} \mathrm{R}-\mathrm{Ab}$ in refractory vascular rejection had only been published 1 year before the patient's episode of rapid loss of graft function and onset of arterial hypertension [7], no baseline measurement of non-HLA-antibodies had been performed prior to transplantation.

Despite antirejection therapy with methylprednisolone pulses, increased tacrolimus exposure (target trough level of $10-12 \mu \mathrm{g} / \mathrm{L}$ ), and pharmacological blockade of the angioten$\sin (\mathrm{AT})$ II pathway by candesartan $(0.1 \mathrm{mg} / \mathrm{kg}$ body weight per day), graft function rapidly declined. Candesartan has the highest affinity for the $\mathrm{AT}_{1} \mathrm{R}$ and was therefore used [17]. Five therapeutic plasma exchange sessions transiently decreased the $\mathrm{AT}_{1} \mathrm{R}-\mathrm{Ab}$ titer from 110 to $25 \mathrm{U} / \mathrm{mL}$, followed by a rapid secondary increase. Transplant function did not recover, and after 6.5 years with a functioning graft, the patient required kidney replacement therapy with hemodialysis. Transplant nephrectomy was performed because of recurrent pyelonephritis and nearly complete loss of transplant function. Histology of the explanted graft showed severe transplant glomerulopathy and severe IFTA. AT $\mathrm{T}_{1} \mathrm{R}-\mathrm{Ab}$ concentration peaked at $276 \mathrm{U} / \mathrm{mL} 16$ months after transplantectomy, then slowly decreased to $55 \mathrm{U} / \mathrm{mL}$ over 2 years but remained persistently elevated (serum concentration around $20 \mathrm{U} / \mathrm{mL}$ ) in the following years. While being on chronic hemodialysis therapy for 4 years, he experienced recurrent thromboembolic events in his central venous (jugular) catheter and arteriovenous fistula without any other known thrombophilic risk factors except high serum $A T_{1} R-A b$. Elevated $A T_{1} R-A b$ might have contributed to these recurrent shunt thromboses, as they stimulate coagulation by inducing tissue factor expression and inhibiting fibrinolysis [13]. Antihypertensive medication was slowly weaned; candesartan was stopped after 3 years.

At the age of 13 years, he received a 2 nd kidney allograft as a living-related transplantation from his mother (one HLA-A, -B, and -DR mismatch each, pre-transplant HLA class I and class II DSA-negative). Because of the persistently elevated $\mathrm{AT}_{1} \mathrm{R}-\mathrm{Ab}$ prior to transplantation, he underwent a desensitization regimen consisting of 15 plasmapheresis sessions (three sessions per week over 5 weeks, each time $150 \%$ exchange of plasma volume with human albumin 5\%), followed by three infusions of intravenous immunoglobulin G (IVIG). The desensitization regimen was based on our local 
desensitization protocol for kidney transplantation across the HLA and ABO barriers (for adults and children) and the protocol for treatment of rejection episodes due to $\mathrm{AT}_{1} \mathrm{R}-\mathrm{Ab}$ in adult patients [7, 18-20], because no published protocol was available for desensitization across the barrier of persisting $\mathrm{AT}_{1} \mathrm{R}-\mathrm{Ab}$. This regimen decreased the $\mathrm{AT}_{1} \mathrm{R}-\mathrm{Ab}$ titer from 19.8 to $9.5 \mathrm{U} / \mathrm{mL}$ and the $\mathrm{ET}_{\mathrm{A}} \mathrm{R}$ antibody titer from 56 to $9.5 \mathrm{U} / \mathrm{mL}$ (Fig. 1). For immunosuppressive induction therapy, the patient received 3-times thymoglobulin i.v. (cumulative dose of $4.5 \mathrm{mg} / \mathrm{kg}$ body weight) and three sessions of plasmapheresis in the first 10 days post-transplant. Immunosuppressive maintenance therapy consisted of tacrolimus (initial dose $0.3 \mathrm{mg} / \mathrm{kg}$ per day), MMF (1200 mg/m² per day), and methylprednisolone. Pharmacological blockade of the AT II pathway by candesartan $(0.15 \mathrm{mg} / \mathrm{kg}$ body weight per day) was resumed on day 10 post-transplant, and therapy with iloprost $(0.5 \mathrm{ng} / \mathrm{kg} / \mathrm{min}$ infused over 6 hours) for 7 days was initiated to improve renal microcirculation, as iloprost attenuates AT II-mediated vasoconstriction [21]. Initial graft function was excellent. A surveillance allograft biopsy on day 17 post-transplant revealed interstitial borderline rejection without signs of vascular rejection; therefore, tacrolimus exposure was increased (target trough level 10-12 $\mu \mathrm{g} / \mathrm{L}$ ).

On day 87 post-transplant, he experienced a rapid decline in transplant function, accompanied by an increase in $\mathrm{AT}_{1} \mathrm{R}$ $\mathrm{Ab}$ and $\mathrm{ET}_{\mathrm{A}} \mathrm{R}-\mathrm{Ab}$ (Fig. 1); in addition, a de novo DSA against the donor mismatch HLA-DQ7 (MFI value $>9000$ by the Luminex single antigen assay) was detected. The histopathological evaluation showed acute interstitial rejection (BANFF 1A) with pronounced IFTA. Antirejection therapy consisted

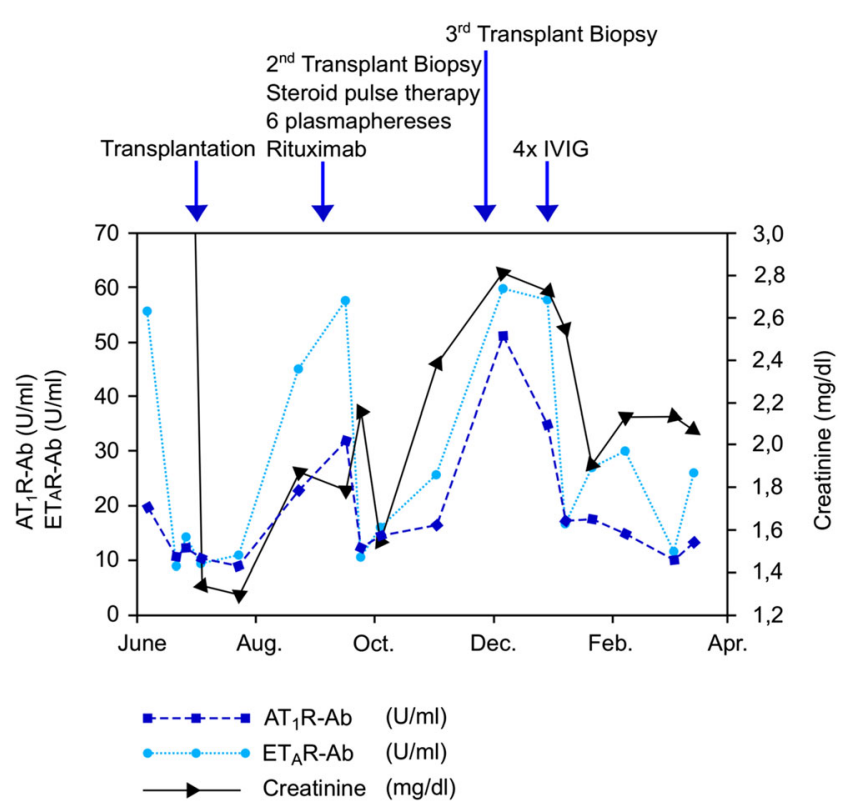

Fig. 1 Course of antibodies against the angiotensin type 1 receptor $\left(A T_{1} R-A b\right)$, the endothelin type $A$ receptor $\left(E_{A} R-A b\right)$, and graft function (serum creatinine) pre-transplant and during the first 10 months after the second kidney transplantation of methylprednisolone pulse therapy, six sessions of plasmapheresis, and one dose of rituximab $\left(375 \mathrm{mg} / \mathrm{m}^{2}\right)$. Furthermore, the patient again received vasodilatory therapy with iloprost (initially once weekly and thereafter every second week). For-cause kidney allograft biopsies on day 123 and day 168 post-transplant were performed due to decreasing kidney function and rising $\mathrm{AT}_{1} \mathrm{R}-\mathrm{Ab}$ and $\mathrm{ET}_{\mathrm{A}} \mathrm{R}-\mathrm{Ab}$ titers; but there were no histopathological signs of acute rejection or accelerated IFTA. In order to reduce antibody titers, three additional sessions of plasmapheresis were conducted, and anti-humoral therapy with high-dose IVIG (four weekly doses, $1 \mathrm{~g} / \mathrm{kg}$ body weight per dose) was administered.

In the following 2 years, serum creatinine slowly increased from 2.0 to $2.8 \mathrm{mg} / \mathrm{dL}$. Besides the DSA against donor mismatch HLA-DQ7 (DQB1*03:01), he also developed a DSA against HLA-DQA1 (DQA1*03:03) and transiently against HLA-DR11 (DRB1*11:01) despite adequate immunosuppressive triple therapy with tacrolimus, MMF and steroids, and good treatment adherence. $\mathrm{AT}_{1} \mathrm{R}-\mathrm{Ab}$ and $\mathrm{ET}_{\mathrm{A}} \mathrm{R}-\mathrm{Ab}$ concentrations remained high with a saturation binding at $>40 \mathrm{U} /$ $\mathrm{mL}$ at most times. His clinical course was further complicated by recurrent episodes of pyelonephritis and pneumonia, which as inflammatory events might have stimulated HLA-DSA and non-HLA antibody formation. Serum creatinine steadily increased; another allograft biopsy at 4 years post-transplant showed chronic ABMR with mononuclear interstitial infiltration, mild tubulitis, C4d positivity in $25 \%$ of the peritubular capillaries, and pronounced IFTA. After 4 years with a functioning graft, he had to resume chronic hemodialysis therapy.

\section{Discussion}

This is the first case report of re-transplantation in a patient who had lost his first graft due to $\mathrm{AT}_{1} \mathrm{R}$-Ab-mediated chronic ABMR. Our data show that an intense desensitization regimen consisting of plasmapheresis and IVIG (to remove circulating $\mathrm{AT}_{1} \mathrm{R}-\mathrm{Ab}$ ) and thymoglobulin (to prevent new antibody production) can transiently decrease elevated $\mathrm{AT}_{1} \mathrm{R}-\mathrm{Ab}$ titers, resulting in stable short-term kidney allograft function. However, the subsequent clinical course was complicated by acute cellular rejection and chronic ABMR, which shortened allograft survival to a period of only 4 years. It is difficult to assess to what extent the persistently elevated $\mathrm{AT}_{1} \mathrm{R}-\mathrm{Ab}$ and $\mathrm{ET}_{\mathrm{A}} \mathrm{R}-\mathrm{Ab}$ titers contributed to allograft injury of his second graft, because he also developed two de novo HLA-DSA, but the unfavorable course of his first graft in the absence of any HLA-DSA render a pathogenic role of elevated $\mathrm{AT}_{1} \mathrm{R}-\mathrm{Ab}$ and $\mathrm{ET}_{\mathrm{A}} \mathrm{R}-\mathrm{Ab}$ quite likely. It is currently not known whether elevated $\mathrm{ET}_{\mathrm{A}} \mathrm{R}-\mathrm{Ab}$ have a pathogenic role for graft rejection independent of elevated $\mathrm{AT}_{1} \mathrm{R}-\mathrm{Ab}$. $\mathrm{AT}_{1} \mathrm{R}-\mathrm{Ab}$ appear to stimulate the development of de novo HLA-DSA [10], and the negative effect of the interplay between $\mathrm{AT}_{1} \mathrm{R}-\mathrm{Ab}$ and HLA- 
DSA on kidney and liver transplant survival has well been demonstrated $[8,16,22]$. Other case series on patients with only $\mathrm{AT}_{1} \mathrm{R}$-Ab-mediated graft injury without HLA-DSA report a more favorable outcome with good long-term graft survival and absence of major complications after adequate anti-humoral therapy $[7,15]$. Whether the sole presence of pre-transplant $\mathrm{AT}_{1} \mathrm{R}-\mathrm{Ab}$ positivity justifies a prophylactic desensitization regimen is still a matter of debate. Carroll et al. investigated in a retrospective single-center study in adult kidney transplant recipients the effect of peri-operative plasma exchange and candesartan in patients with high pretransplant $\mathrm{AT}_{1} \mathrm{R}-\mathrm{Ab}$ positivity and observed that this perioperative regimen may alter the risk of rejection compared to a historical control group [23], but further studies are needed.

An elevated $\mathrm{AT}_{1} \mathrm{R}-\mathrm{Ab}$ and $\mathrm{ET}_{\mathrm{A}} \mathrm{R}-\mathrm{Ab}$ titer may induce severe arterial hypertension. These antibodies lead to a sustained activation of the $\mathrm{AT}_{1} \mathrm{R}$ and $\mathrm{ET}_{\mathrm{A}} \mathrm{R}$, which stimulates vasoconstriction via G-protein coupling [7] and upregulation of the respective receptor expression at the target cell membrane [10]. While we previously observed an association of $\mathrm{AT}_{1} \mathrm{R}-$ $\mathrm{Ab}$ positivity and higher systolic blood pressure in pediatric kidney transplanted patients [8], this association was not observed in the study of Pearl et al. [24]. The pathophysiological relevance of these antibodies for arterial hypertension remains therefore to be elucidated. The variable clinical phenotype of high $\mathrm{AT}_{1} \mathrm{R}-\mathrm{Ab}$ positivity may be explained by interindividually different (genotypic) receptor expression at the target cell membrane, different autoantibody epitopes with variable agonistic function, or a desensitization of the postreceptor pathway in endothelial cells due to persisting activation of the $\mathrm{AT}_{1} \mathrm{R}$ [10].

This case also highlights the medical need to develop more effective therapies against elevated $\mathrm{AT}_{1} \mathrm{R}-\mathrm{Ab}$ and $\mathrm{ET}_{\mathrm{A}} \mathrm{R}-\mathrm{Ab}$. Our conventional multimodal therapeutic approach, which was used in analogy to barrier transplantations in patients highly immunized against HLA antigens, led only to a partial and transient reduction of $\mathrm{AT}_{1} \mathrm{R}-\mathrm{Ab}$ and $\mathrm{ET}_{\mathrm{A}} \mathrm{R}-\mathrm{Ab}$ titers with an overall unsatisfactory clinical course. It remains to be seen whether newer induction regimens with other anti-B cell biologicals such as daratumumab, perhaps in conjunction with the dual $\mathrm{AT}_{1} \mathrm{R}$ and $\mathrm{ET}_{\mathrm{A}} \mathrm{R}$ blocker sparsentan, allow a more favorable outcome in these difficult-to-treat patients.

Funding Open Access funding enabled and organized by Projekt DEAL.

\section{Compliance with ethical standards}

Conflict of interest The authors declare that they have no conflicts of interest.

Open Access This article is licensed under a Creative Commons Attribution 4.0 International License, which permits use, sharing, adaptation, distribution and reproduction in any medium or format, as long as you give appropriate credit to the original author(s) and the source, provide a link to the Creative Commons licence, and indicate if changes were made. The images or other third party material in this article are included in the article's Creative Commons licence, unless indicated otherwise in a credit line to the material. If material is not included in the article's Creative Commons licence and your intended use is not permitted by statutory regulation or exceeds the permitted use, you will need to obtain permission directly from the copyright holder. To view a copy of this licence, visit http://creativecommons.org/licenses/by/4.0/.

\section{References}

1. Einecke G, Sis B, Reeve J, Mengel M, Campbell PM, Hidalgo LG, Kaplan B, Halloran PF (2009) Antibody-mediated microcirculation injury is the major cause of late kidney transplant failure. Am J Transplant 9:2520-2531

2. Süsal C, Fichtner A, Tönshoff B, Mehrabi A, Zeier M, Morath C (2017) Clinical relevance of HLA antibodies in kidney transplantation: recent data from the Heidelberg Transplant Center and the Collaborative Transplant Study. J Immunol Res 2017:5619402

3. Lee P-C, Zhu L, Terasaki PI, Everly MJ (2009) HLA-specific antibodies developed in the first year posttransplant are predictive of chronic rejection and renal graft loss. Transplantation 88:568-574

4. Chaudhuri A, Ozawa M, Everly MJ, Ettenger R, Dharnidharka V, Benfield M, Mathias R, Portale A, McDonald R, Harmon W, Kershaw D, Vehaskari VM, Kamil E, Baluarte HJ, Warady B, Li L, Sigdel TK, Hsieh SC, Dai H, Naesens M, Waskerwitz J, Salvatierra O, Terasaki PI, Sarwal MM (2013) The clinical impact of humoral immunity in pediatric renal transplantation. J Am Soc Nephrol 24:655-664

5. Zhang X, Reinsmoen NL (2020) Impact and production of NonHLA-specific antibodies in solid organ transplantation. Int $J$ Immunogenet 47:235-242

6. Dragun D, Catar R, Philippe A (2016) Non-HLA antibodies against endothelial targets bridging allo- and autoimmunity. Kidney Int 90: 280-288

7. Dragun D, Müller DN, Bräsen JH, Fritsche L, Nieminen-Kelhä M, Dechend R, Kintscher U, Rudolph B, Hoebeke J, Eckert D, Mazak I, Plehm R, Schönemann C, Unger T, Budde K, Neumayer H-H, Luft FC, Wallukat G (2005) Angiotensin II type 1-receptor activating antibodies in renal-allograft rejection. N Engl J Med 352:558569

8. Fichtner A, Süsal C, Schröder C, Höcker B, Rieger S, Waldherr R, Westhoff JH, Sander A, Dragun D, Tönshoff B (2018) Association of angiotensin II type 1 receptor antibodies with graft histology, function and survival in paediatric renal transplant recipients. Nephrol Dial Transplant 33:1065-1072

9. Lefaucheur C, Viglietti D, Bouatou Y, Philippe A, Pievani D, Aubert O, Duong Van Huyen JP, Taupin JL, Glotz D, Legendre C, Loupy A, Halloran PF, Dragun D (2019) Non-HLA agonistic anti-angiotensin II type 1 receptor antibodies induce a distinctive phenotype of antibody-mediated rejection in kidney transplant recipients. Kidney Int 96:189-201

10. Philogene MC, Johnson T, Vaught AJ, Zakaria S, Fedarko N (2019) Antibodies against angiotensin II type 1 and endothelin A receptors: relevance and pathogenicity. Hum Immunol 80:561-567

11. Reinsmoen NL (2013) Role of angiotensin II type 1 receptoractivating antibodies in solid organ transplantation. Hum Immunol 74:1474-1477

12. Jobert A, Rao N, Deayton S, Bennett GD, Brealey J, Nolan J, Carroll RP, Dragun D, Coates PT (2015) Angiotensin II type 1 receptor antibody precipitating acute vascular rejection in kidney transplantation. Nephrology 20:10-12

13. Pearl MH, Reed EF (2019) Angiotensin II type I receptor antibodies in pediatric solid organ transplant. Hum Immunol 80:568-572 
14. Kelsch R, Everding AS, Kuwertz-Bröking E, Brand E, Spriewald BM, Sibrowski W, Konrad M, Dragun D (2011) Accelerated kidney transplant rejection and hypertensive encephalopathy in a pediatric patient associated with antibodies against angiotensin type 1 receptor and HLA class II. Transplantation 92:e57-e59

15. Guzzo I, Morolli F, Camassei FD, Piazza A, Poggi E, dello Strologo L (2017) Acute kidney transplant rejection mediated by angiotensin II type 1 receptor antibodies in a pediatric hyperimmune patient. Pediatr Nephrol 32:185-188

16. Reinsmoen NL (2019) Compelling scientific and clinical evidence that non-HLA specific antibodies impact graft outcome independently and in concert with donor HLA specific antibodies. Hum Immunol 80:555-560

17. Fabiani ME, Dinh DT, Nassis L, Casley DJ, Johnston CI (2000) In vivo inhibition of angiotensin receptors in the rat kidney by candesartan cilexetil: a comparison with losartan. Am J Hypertens 13:1005-1013

18. Morath C, Beimler J, Opelz G, Ovens J, Scherer S, Schmidt J, Schmied B, Gross M-L, Schwenger V, Zeier M, Süsal C (2010) An integrative approach for the transplantation of high-risk sensitized patients. Transplantation 90:645-653

19. Speer C, Kälble F, Nusshag C, Pego da Silva L, Schaier M, Becker LE, Klein K, Sommerer C, Beimler J, Leo A, Waldherr R, Mehrabi A, Süsal C, Zeier M, Morath C (2019) Outcomes and complications following $\mathrm{ABO}$-incompatible kidney transplantation performed after desensitization by semi-selective immunoadsorption - a retrospective study. Transpl Int 32:1286-1296
20. Beimler JHM, Susal C, Zeier M (2006) Desensitization strategies enabling successful renal transplantation in highly sensitized patients. Clin Transpl 20:7-12

21. Purdy K, Arendshorst WJ (2001) Iloprost inhibits inositol-1,4,5trisphosphate-mediated calcium mobilization stimulated by angiotensin II in cultured preglomerular vascular smooth muscle cells. J Am Soc Nephrol 12:19

22. Taniguchi M, Rebellato LM, Cai J, Hopfield J, Briley KP, Haisch CE, Catrou PG, Bolin P, Parker K, Kendrick WT, Kendrick SA, Harland RC, Terasaki PI (2013) Higher risk of kidney graft failure in the presence of anti-angiotensin II Type-1 receptor antibodies. Am J Transplant 13:2577-2589

23. Carroll RP, Riceman M, Hope CM, Zeng A, Deayton S, Bennett GD, Coates PT (2016) Angiotensin II type-1 receptor antibody (AT1Rab) associated humoral rejection and the effect of peri operative plasma exchange and candesartan. Hum Immunol 77:1154 1158

24. Pearl MH, Zhang Q, Diaz MFP, Grotts J, Rossetti M, Elashoff D, Gjertson DW, Weng P, Reed EF, Chambers ET (2018) Angiotensin II type 1 receptor antibodies are associated with inflammatory cytokines and poor clinical outcomes in pediatric kidney transplantation. Kidney Int 93:260-269

Publisher's note Springer Nature remains neutral with regard to jurisdictional claims in published maps and institutional affiliations. 